\title{
К вопросу о профессиональных стандартах и этических регуляторах журналиста информагентства
}

Татьяна Курманина

В статье анализируются представленные в научной литературе этические принципы, которыми руководствуется в профессиональной деятельности корреспондент, занимающийся поиском, обработкой и оперативной подачей новостной информации. Приведены основные понятия, определяющие культуру корреспондента информационного агентства, который должен обладать определенными умениями и навыками, знать нормы и принципы, выстраивать стратегию поведения. Опираясь на собственный опыт работы в информационном агентстве, автор определяет необходимые личные качества для специалиста подобной новостной службы.

Ключевые слова: информационное агентство, информационные стандарты, культура журналиста, этические нормы.
@ Курманина Татьяна Сергеевна аспирантка Института филологии и журналистики ННГУ им. Н.И. Лобачевского, корреспондент информагентства «Интерфакс-Поволжье» в Нижегородской области

(г. Нижний Новгород, Россия), tkurmanina@mail.ru
В современной России информационные агентства (ИА) стали не просто крупными центрами фильтрации и почти мгновенной обработки постоянно поступающей информации. Агентства задают вектор для деятельности всей системы средств массовой информации, в том числе в вопросах планки профессиональных стандартов своих сотрудников.

Специфика функционирования агентств, стилистические и жанровые особенности информационных материалов находятся в поле зрения видных ученых (см.: Вартанова, Вирен, Фролова, 2013; Вирен, Фролова, 2015; Дзялошинский, Дзялошинская, 2016; Лазутина, Клёсова, Кульчицкая, 2011; Могилевская, 2008; Сапунов, 2006). Авторы в основном определяли роль агентств на медиарынке, изучали различия и сходства существующих новостных служб, рассматривали жанровую специфику сообщений. В то же время в научной литературе рассмотрению профессиональных этических аспектов, вопросов соблюдения информационных и законодательных стандартов корреспондентами ИА при передаче важных сообщений внимания уделялось гораздо меньше.

Между тем практика показывает, что методы работы с источниками и способы получения поводов для новости информационными агентствами существенно 
влияют на профессиональные стандарты всей журналистики. Фактически информационные агентства формируют повестку для остальных медиа, а стандарты работы и этические регуляторы корреспондентов ИА задают планку для работы других профессионалов. Однако названные процессы до сих пор оставались без должного внимания исследователей.

В связи с этим задачей настоящего исследования является рассмотрение основных этических принципов деятельности, присущих журналистам информационных агентств. Целью - систематизация основных принципов, которыми руководствуются корреспонденты-новостники, вне зависимости от источников финансирования, руководящего состава и редакционных установок ИА, в которых они работают. Опираясь на анализ теоретической литературы и законодательных документов, применяя метод включенного наблюдения, автор уточняет необходимые компетенции для специалиста, который работает в новостной службе, а также определяет набор профессиональных качеств - знание соответствующих законов, информационных стандартов, законодательной базы той области, в которой специализируется корреспондент.

\section{Ориентиры в повестке медиа}

С момента своего образования и на протяжении почти 150-летней истории существования информационные агентства стоят во главе системы СМИ и понимаются как службы, оперативно собирающие факты "оптом», а впоследствии платно распространяющие их в «розницу».

К ряду существующих формулировок ИА исследователь Т.И. Фролова (Засурский (ред.), 2006: 356) дает следующее определение: «Информационные агентства являются специализированными информационными предприятиями (организации, службы, центры), обслуживающими СМИ».
Их основной функцией является снабжение оперативной политической, экономической, социальной, культурной информацией редакций печатных и электронных СМИ, телевидения, радиовещания, а также других учреждений, в том числе и частных, которые подписаны на их продукцию.

Петербургский ученый М.Н. Ким (2005: 209) уточняет, что «в информационных материалах, исходя из принципов объективности, желательно отделять факты от мнений, от оценок, от различного рода интерпретаций, версий и предположений». У информационных агентств основообразующим является принцип непредвзятости к отбору правдивой информации и создание на его основе актуальных и востребованных материалов. Каждое агентство соблюдает положения общего для всех средств массовой информации Кодекса профессиональной этики журналиста, однако у каждой новостной службы разработаны собственные стандарты, которым обязан следовать сотрудник. В числе подобного свода правил обычно содержится регламент работы с источниками информации, правила написания текстов и технология передачи новостей.

Однако главным в стандарте, как правило, является раздел о требованиях и критериях качества, предъявляемых к сотрудникам агентств, - корреспондентам и выпускающим редакторам. У трех ведущих отечественных информационных агентств существуют подобные внутриредакционные документы - у агентств «Интерфакс»1, «РИА Новости»² и ТАСС ${ }^{3}$ стандарты распространяются как внутри компании, так и размещены в открытом доступе, служат учебными пособиями в вузах для преподавателей и студентов.

Анализируя этическую часть публичных внутренних документов информационных агентств, констатируем, что значительное количество требований совпадает с положениями действующего в РФ Закона о СМИ, 
а именно с 49 статьей, где излагаются основные обязанности журналиста. При этом важным для сотрудника является следование третьей части данной статьи, где прописан порядок работы с источником, под которым понимается обязанность журналиста «удовлетворять просьбы лиц, предоставивших информацию, об указании на ее источник, а также об авторизации цитируемого высказывания, если оно оглашается впервые». Специалисты агентств, получая информацию от источника, должны предпринять все усилия для подтверждения официальной позиции компетентного ведомства о происходящем, только тогда новость считается объективной и полной. Кроме того, ряд положений информационных стандартов совпадает и с прописанными положениями Кодекса профессиональной этики журналиста 5 .

Изучая имеющиеся в открытом доступе профессиональные стандарты (см. табл.), можно найти схожие для корреспондентов рекомендации. Соблюдение корреспондентами этих базовых принципов, по мнению составителей документов, с большой вероятностью должно улучшить качество работы всего агентства.

\section{Способы получения информации}

Принципы работы информационных агентств во всем мире схожи: корреспондент специализируется на определенной области (экономика и финансы, судебная система, политика, энергетика, выборы, машиностроение, соцсфера) и отслеживает в ней изменения в непрерывном формате. Каждый сотрудник составляет индивидуальный план из анонсов определенных событий в своем «поле работы», который в результате входит в общий график работы всего агентства. Таким образом агентство знает, что в определенный момент времени должно произойти конкретное событие, однако если оно закрыто от прессы или о нем журналистам не сообщают в форме пресс-релизов, то сотрудник сам выясняет, что произошло. При этом важно отметить, что агентство исходит из того, что до корреспондента никто об этом событии еще не знает, поэтому при выяснении информации он должен:

- точно убедиться в правильном понимании того, что происходит;

- разграничивать компетенции комментирующих событие спикеров;

- сопроводить новую информацию предысторией по теме - для понимания важности и значимости произошедшего для читателя.

На основании вышесказанного можно утверждать, что оперативное реагирование на происходящее является ключевой характеристикой, отличающей корреспондента информагентств от журналистов других СМИ. Время от обработки информационной «наводки» до финальной публикации может занимать несколько минут. В этом случае оперативность трактуется как величина временного отрезка, отделяющего момент самого события от момента получения информации об этом событии адресатом. Следование принципам оперативности не должно оказывать влияния на соблюдение точности, под которой понимается фактологическое соответствие названий ведомств, имен спикеров, географических названий и т.д.

Стоит также обратить внимание на проведение постоянного мониторинга корреспондентом ИА событий в той сфере, в которой он специализируется. Важным является то, что наблюдение ведется не только за публикациями в официальных СМИ, информационный поток отслеживается также в социальных сетях, каналах в мессенджерах и форумах с локальными новостями. На перечисленных платформах часто происходит оперативная трансляция с места события со ссылкой на очевидцев. Как только специалист ИА увидел интересную и важную историю, он сразу 


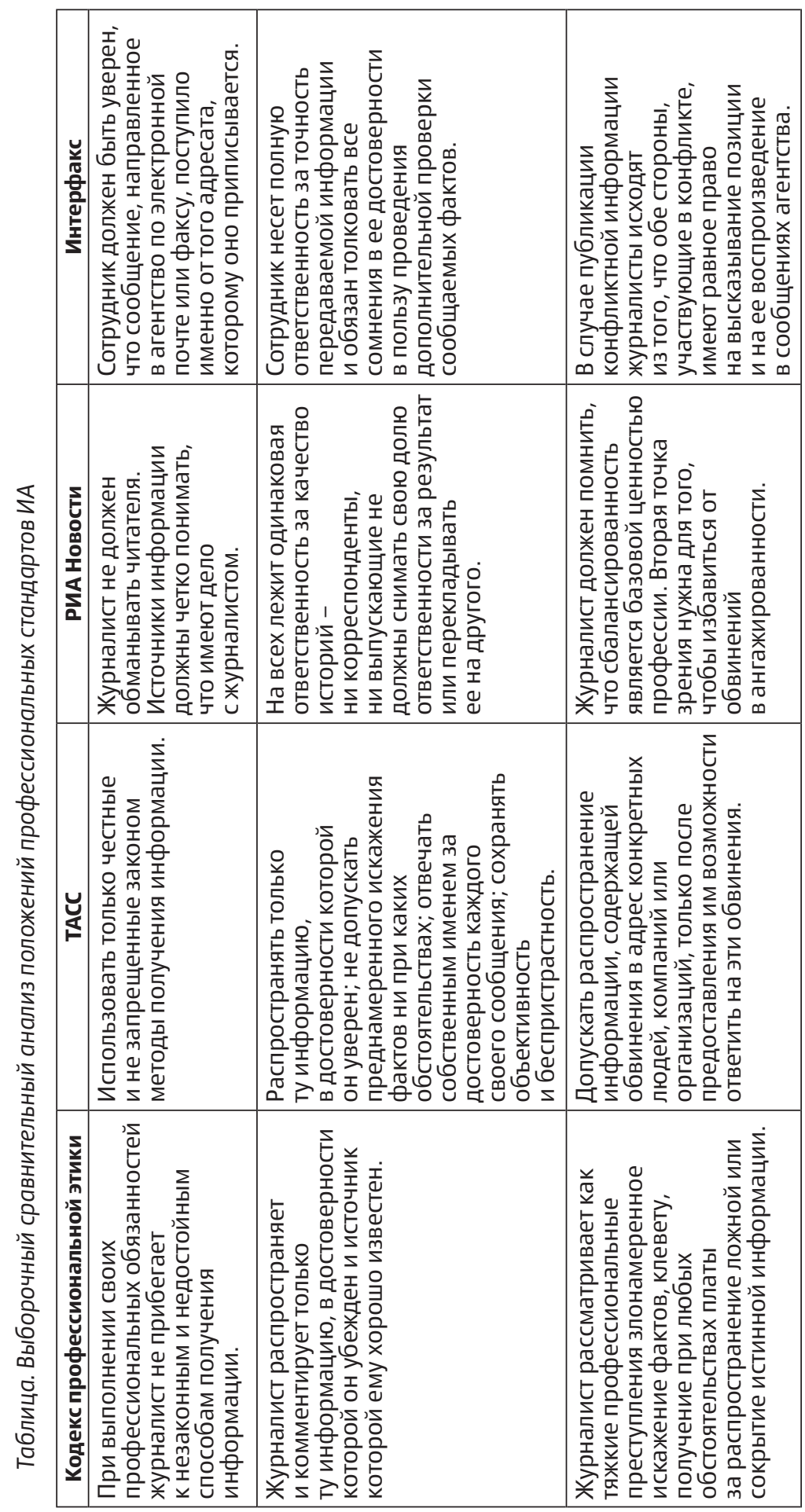


же верифицирует эту информацию через официальные источники, а затем следит за ее развитием.

Отметим, что профессионализм работника оценивается по широкому кругозору, коммуникабельности, а также умению быстро завоевать доверие собеседника для оперативного получения необходимых сведений. В связи с этим можно сделать вывод, что корреспондент информационного агентства не просто журналист, он отчасти и детектив, и архивариус, и дипломат. Специалист не может знать все обо всем, однако он должен быстро связаться с профессионалами своего дела, которые могут наиболее полно и понятно рассказать ему о происходящем.

Кроме того, корреспондента информагентства отличает отсутствие любой эмоциональной оценки предмета сообщения. При подготовке и написании новости сотруднику запрещается добавлять собственные интерпретации о причинах, ходе событий, вероятных прогнозах и последствиях. В результате подписчики агентств получают сухой факт, и они трактуют информационную заметку так, как позволяет им личный жизненный опыт.

\section{Ошибки информационного агентства}

Преждевременная публикация сообщения, передача непроверенного факта от недостоверного источника приводит к дальнейшему аннулированию новости, что в работе агентства считается чрезвычайной ситуацией. Данный процесс представляет собой удаление из доступа подписчиков новости с выходными данными, с обязательным примечанием о причине этого и извинениями в адрес подписчиков. Приведем несколько примеров аннулирования новости из практики трех крупнейших отечественных информагентств:

1. «Интерфакс» - аннулирование новости от 2 сентября 2015 г., выпущенной в 18:05 мск: «Новость с заголовком “Скончался президент Узбекистана Ислам Каримов" вышла в результате технического сбоя. "Интерфакс" приносит извинения подписчикам и читателям».

2. «РИА Новости» - аннулирование новости от 1 февраля 2019 г., выпущенной в 20:13 мск: «Сообщение со ссылкой на официального представителя МИД РФ Марию Захарову о том, что Россия по-прежнему согласна вести с США диалог по ДРСМД, было выпущено ошибочно. В связи с этим "РИА Новости" аннулирует его. Агентство приносит извинения читателям и подписчикам».

3. ТАСС - аннулирование новости от 26 июня 2019 г., выпущенной в 13:40 мск: «Новость "Ушаков: Путин на полях саммита G20 встретится с главами Франции, ФРГ, Турции и Египта", выпущенная на tass.ru 26 июня в 13:40 мск, аннулируется как выпущенная ошибочно. ТАСС приносит извинения своим подписчикам и читателям».

Проанализировав статистику аннулированых новостей с января 2017 г. до августа 2019 г. можно сделать вывод, что агентство ТАСС аннулировало свои сообщения 66 раз, «Интерфакс» - 40, «РИА Новости» 37. При этом важно отметить, что удаление текста из доступа для подписчиков чаще всего было связано с тем, что новость «вышла ошибочно», «в связи с некорректным переводом первоначальной новости», «в связи с техническим сбоем».

Аннулированные сообщения у ТАСС и «РИА Новости» чаще всего касались социально-политической темы, у «Интерфакса» финансово-экономической. На основании собственного опыта автор считает немаловажным подчеркнуть, что удаление политических новостей чаще может быть вызвано ошибкой корреспондента, финансовых - неточностями в официальных пресс-релизах компаний и неподтверждением официальными структурами информации источников рынка.

Ошибки в социально-политических сообщениях могут быть мотивированы спешкой 
при передаче экстренного сообщения, халатностью с дополнительной проверкой важной информации, то есть несоблюдением правил внутриредакционного стандарта информационного агентства. За аннулирование сообщений корреспонденту и его непосредственным руководителям грозит дисциплинарная ответственность выговор, штрафы, увольнение.

В то же время для других СМИ аннулирование сообщения агентством является в определенной степени информационным поводом, поскольку издания могут сделать отдельные материалы об удалении новости агентством:

- Сайт газеты «Ведомости», 16 ноября 2015 г.: «"Интерфакс "аннулировал новость о запрете поездок в Европу».

- Сайт газеты «Московский комсомолец», 12 января 2011 г.: «"РИА Новости" аннулировало сообщение о признании судом законности ареста Немцова».

- Сайт «Газета.ru», 15 марта 2019 г.: «ТАСС аннулировал сообщение об отмене MAKC-2019».

Кроме того, СМИ могут анализировать предпосылки аннулирования сообщения ИА, подводить статистику по количеству подобных действий определенным агентством за конкретный временной промежуток.

Подписчики получают информационную продукцию в режиме «нон-стоп» на платных условиях, и частое аннулирование сообщений редакциями может привести к отказу абонентов от подписки. В конечном счете это негативно скажется на репутации новостной службы как авторитетного источника информации, приведет к снижению цитируемости СМИ, поэтому корреспонденты обязаны минимизировать вероятность допущения подобных ошибок.

\section{Выводы}

На основании вышеизложенного можно сделать вывод, что сотрудник новостной службы должен обладать широким кругозором, очень высокой оперативностью, способностью быстро выделять из контекста главное и новое для читателей, коммуникабельностью, дружелюбностью, готовностью к постоянному самообразованию, и при этом на каждом этапе своей деятельности осознавать личную ответственность.

Для корреспондентов информаци онных агентств составлены профессиональные стандарты, которые поясняют основные принципы их работы. При этом большинство положений внутриредакционных документов касаются порядка работы с источником, принципов выяснения и публикации достоверных фактов.

В соответствии с требованиями руководства каждый сотрудник информационного агентства должен подписать эти внутренние документы, тем самым взяв на себя обязательства следовать им в своей работе. Несоблюдение профессиональных рекомендаций в стандарте может привести к аннулированию корреспондентом переданной информации. Во всех редакционных стандартах отмечается, что подобные ошибки, возникшие от незнания либо некомпетентности корреспондента, разрушают репутацию агентства.

Удаление новости по вине журналиста влечет ущерб для клиентов агентства и может спровоцировать их отказ от подписки, которая, в свою очередь, является одним из основных способов заработка для ИА. Кроме того, нарушение внутриредакционного стандарта может повлечь серьезные финансовые санкции, в худшем случае - увольнение по инициативе работодателя за несоблюдение инструкций. Таким образом, от внимательности и корректности журналиста информационного агентства в работе зависит не только его личная профессиональная репутация, но и статус агентства на медиарынке. 


\section{Примечания}

${ }^{1}$ Информационный стандарт группы «Интерфакс». М.: Изд-во Моск. ун-та, 2009.

2 Редакционные принципы работы Главной дирекции информации ФГУП РАМИ «РИА Новости». М.: Аспект Пресс, 2007.

3 Редакционный стандарт ТАСС: учеб. пособие для студентов / авт.-сост. А.В. Лебедев; отв. ред. М.Г. Филимонов. М.: Аспект Пресс, 2019.

4 Закон РФ от 27.12.1991. № 2124-1 (ред. от 18.04.2018) «О средствах массовой информации», ст. 49. Режим доступа: https://rg.ru/1991/12/27/smi-zakon.html

${ }^{5}$ Кодекс профессиональной этики журналиста от 24.04.1991. Режим доступа: https://online.zakon.kz/Document/?doc_id=30353759

\section{Библиография}

Вартанова Е.Л., Вирен Г.В., Фролова Т.И. Типология информационных агентств // Вестн. Моск. ун-та. Сер. 10: Журналистика. 2013. № 3. С. 6-30.

Вирен Г.В., Фролова Т.И. Информационные агентства. Как создаются новости. М.: Аспект Пресс, 2015. С. 30-45.

Дзялошинский И.М., Дзялошинская М.И. Журналистские кодексы и журналистская практика: непересекающиеся параллели? // Гуманитарный вектор. 2016. Т. 11. № 5. C. 100-109.

Ким М.Н. Новостная журналистика. Базовый курс. СПб.: Изд-во Михайлова В.А., 2005.

Лазутина Г.В., Клёсова О.А., Кульчицкая Д.Ю. Поиск ответственной журналистики (по мотивам круглого стола) // Вестн. Моск. ун-та. Сер. 10: Журналистика. 2011. № 5. C. 55-68.

Могилевская Э.В. Информационные агентства в Интернете: особенности и принципы функционирования: дис. ... канд. филол. наук. Тольяти, 2008.

Сапунов В.И. Зарубежные информационные агентства. СПб.: Изд-во Михайлова В.А., 2006.

Средства массовой информации России: учеб. пособие для студентов вузов / М.И. Алексеева, Л.Д. Болотова, Е.Л. Вартанова и др. / под ред. Я.Н. Засурского. М.: Аспект Пресс, 2006. 